\title{
ГЕНЕАЛОГИЈА СВАКОДНЕВИЦЕ: СЛОВЕНАЧКА ПОЕЗИЈА У ТРАНЗИЦИЈИ
}

Филозофски факултет Универзитета у Љубљани

Апстракт: У раду покушавам да дефинишем и опишем промене песничке парадигме у новијој словеначкој поезији која се отргла од модернистичке парадигме и прешла на парадигму песништва након модернизма. Зато ова поезија није постмодернистичка, како ју је најпре класификовала словеначка књижевна наука већ антимодернистичка будући да покушава да побегне од „великих“ тема песничког модернизма, а у неким случајевима и од његових поступака. У опису поменуте промене парадигме ослањамо се на дистинкцију између „куване“ и „сирове“ поезије (cooked/raw poetry) коју је на трагу Леви-Строса увео Роберт Ловел за америчку поезију након Другог светског рата. Након прегледа песничког контекста словеначке поезије у осамдесетим годинама XX века, наше истраживање се усредсређује на 1991. годину. У ту сврху потребна нам је извесна књижевноисторијска сондажа која омогућава увид у ситуацију у којој се на почетку деведесетих година словеначка поезија нашла у расцепу између две тенденције, то јест, између „високе“, „куване“ поезије модернистичког типа, која се фокусира на „високу“ егзистенцијалистичку тематику по узору на поезију Данеа Зајца и других водећих песничких гласова словеначке модернистичке поезије, и „ниске“, „сирове“ поезије која покушава да се удаљи од остатака метафизичке традиције и тематизује свакодневно урбано искуство користећи релаксиран, неретко наративан језик. Поезија Томажа Шаламуна представља главни домаћи утицај ове врсте поезије, док од утицаја који долазе са стране ваља поменути америчко песништво beat генерације и њујоршку школу.

Кључне речи: модернизам, свакодневица, „сирова поезија“ (raw poetry), beat генерација, Томаж Шаламун, савремена словеначка поезија, 1991. година

У овом чланку покушаћу да покажем да се у словеначкој поезији с почетка деведесетих година, нарочито код песника који тада почињу да објављују, присутна извесна дихотомија између књижевног наслеђа модернизма и нове поетике која је почела да се опире овој поетици. Ова дихотомија, наравно, нема функцију строге бинарне опозиције која би детаљно дефинисала сваки песнички текст који у овом периоду настаје већ је пре реч о покушају дескрипције две главне тенденције које представљају једну од могућих књижевноисторијских рефлексија о новијој словеначкој поезији, због чега немамо намеру да успоставимо дефинитивну теоријску

1 Чланак је написан у оквиру пројекта J6-8259, који је Јавна агенција за истраживачку делатност Републике Словеније суфинансирала из државног буџета. 
констелацију, будући да мноштво књижевних текстова поменуту дихотомију и опозицију непрестано оповргава, што посебно важи за време кад песничка продукција нараста до непрегледности.

О каквој дихотомији је овде реч? На словеначкој песничкој сцени с једне стране имамо неку врсту умереног модернизма који се у већини случајева опире радикалним авангардистичким семантичким и синтаксичким деструкцијама традиционалног песничког говора бавећи се пре свега егзистенцијалистичким темама, то јест, питањем о истини света, смислу постојања, смрти, слободи итд. Другим речима, ипак постоји интересовање за традиционална метафизичка питања којима се са стилско-формалног аспекта приступа различитим поступцима, од слободног стиха до традиционалних песничких форми какав је, на пример, сонет. Вероватно је најмањи заједнички садржалац поезије овог типа у Словенији коришћење (пост)симболистичких језичких стратегија ${ }^{2}$ као што су згуснут језик, семантички непрозирне метафоре, естетицизам који каткад склизне у сасвим херметичан говор који само својеврсним шифрама указује на неизрециво као стварну и увек недостижну супстанцу ове врсте песништва. У вези с овим песничким наслеђем словеначка књижевна наука (с Јанком Косом на челу, 1995а: 181) често је наглашавала да модерну и модернистичку поезију у основи одређује тзв. метафизички нихилизам, то јест, свест о одсутности традиционалне трансценденције, свест о онтолошком ништавилу као истини свега, и будући да је он у основи неодржив, оваква модернистичка поезија га на различите начине, у оквиру различитих ауторских поетика, превазилази или преболева. Овде је, дакле, реч о поезији која је озбиљна, култивисана, естетска, узвишена јер се дотиче најдубљих питања човекове егзистенције и устројства света. ${ }^{3}$ Након Другог светског рата два водећа песника ове поетике, свако на свој начин, јесу Дане Зајц (1929-2005) и Грегор Стрниша (19301987). Поред њих поменимо још Вена Тауфера (1933), Кајетана Ковича (1931-2014), Светлану Макарович (1939), Јожу Сноја (1934) и друге.

2 На овом месту мислим на (пост)симболизам у смислу књижевног правца који је по мишљењу Јанка Коса још увек веома присутан у словеначкој поезији друге половине XX века. Док је за симболизам карактеристично да је метафизичка трансценденција још увек доступна преко симбола, постсимболизам се метафизике одриче до краја, као што каже Јанко Кос, у њему нестаје „првотна извесност опевања поетичке метафизике помоћу симбола“" (2000: 345).

3 Узевши у обзир такву поезију можемо тврдити да она у себи још увек скрива романтичну тежњу за изрицањем неизрецивог, Апсолутног и да се тако схвата себе као привилегован, квазисакралан говор који се на основу маште, као примарне изнад разума постављене људске сазнајне могућности, ипак опире распаду традиционалног света и поступној дисоцијацији субјекта. Зато се можемо сложити с Албертом Гелпијем, који до сличних закључака долази у вези с америчким (касним) модернизмом (2015: 5) и поред осталог наглашава да овај песнички модернизам управо својом „доктрином“ о естетској монолитности, односно целовитости песме ефектно компензује фрагментарно искуство стварности савременог секуларног Запада којом више није могуће овладати. 
С друге стране имамо поезију коју бисмо услед недостатка јасног означитеља могли назвати поезија свакодневице, која тематизује свакидашњицу, овострано „метафизичко“ животно искуство које повремено у потпуно песничком маниру, не скривајући разне детаље из личног живота, открива индивидуалност, каткад саму приватност (урбане) свакидашњице појединца. Стога таква поезија може да делује антимодернистички, али не као супротност модернизму већ као уметничка артикулација која покушава коначно да деконструише романтичарске рецидиве унутар самог модернизма, као отпор против новог, наводно естетског елитизма, као отпор против тога да ова поезија својим (наводним $)^{4}$ формализмом, херметизмом и естетицизмом функционише као сурогат религије у секуларизованом свету, односно, у слабијем значењу, она чак запада у сажаљење над самом собом, позу, апстрактност или пуки декор. На формално-стилској равни овај отпор често се изражава деметафоризацијом, демелодизацијом и деритмизацијом песничког језика, тако да преовладава слободни стих и релаксиран приповедачки тон, чиме се он приближава спонтаности говорног језика, што свакако подразумева и укључивање идиолеката, сленга, референци из популарне културе, једноставан хумор и иронију, који у поезији поменутог умереног модернизма углавном изостају. Такав отпор романтизму који верује у могућност отпора и нове, сасвим другачије поезије, на крају и сам пристаје на романтизам. Песме ове врсте често су производ стабилног субјекта који приповеда песме с површине своје (ауто)биографске приватности. Штавише, на том нивоу оне могу деловати чак предромантичарски уколико се у свакој властитој приватности или чак баналности не уздигну над монотонијом својеврсне урбане анакреонтике. Њихов стабилан субјект, експлицитно усмерен у релаксирану овостраност, често подсећа на хедонизам просветитељске анакреонтике који у облику лежерних пивских и еротичких песама измиче свакој озбиљнијој етичкој и егзистенцијалној тематици.

Крајем осамдесетих и почетком деведесетих година у словеначкој поезији се успоставило стање напетости између „куване“ и „сирове“ поезије, ако се позајми кулинарска дистинкција коју је амерички песник Роберт Ловел у свом говору 1960. године на додели признања National Book Award за збирку Life Studies, употребио да означи америчку поезију педесетих година XX века. Као што је познато, ову луцидну дистинкцију, која се имплицитно надовезује на Леви-Стросову везану за подручје структуралне антропологије,

4 Овде свесно користим реч „наводно“ будући да је у тој реакцији против традиције - као и код свих промена парадигме - пуно редукције, нивелизације на оно што је у претходном преовладавајућем стилу лоше, истрошено, репетативно. Морам да нагласим да овде није реч о некој врсти аксиолошке проблематизације оба типа поетика већ само о књижевноисторијској дескрипцији. 
посредством разних аналогија, знатно касније у потпуности је присвојио критички универзитетски дискурс о послератној америчкој поезији, што можемо да пратимо и данас (Swensen 2009: xvii-xxvi). За Ловела је кувана поезија (cooked poetry) култивисана, „интелектуалистичка“ поезија коју називају још педантном поезијом (poetry of pedantry), какву је писао, рецимо, Т. С. Елиот, али и други амерички песнички модернисти као што су (рани) Езра Паунд, Харолд Харт Крејн итд. Овакву поезију је у годинама након Другог светског рата више ценио универзитетски дискурс (пре свега тзв. New Criticism), док је „сирова“ поезија (raw poetry), која стоји насупрот педантној поезији, „поезија скандала“ (poetry of scandal), одраз непосредног, спонтаног искуства, односно, као што каже Ловел, незачињеног искуства (unseasoned experience) (Gould Axelrod 1978: 253), то јест живота таквог какав јесте, ако под тим подразумевамо „просечно“, свакодневно, обично, овосветско или чак тривијално животно искуство (типичног западњака), унутар кога може доћи до неког магичног открића свакодневног момента у некој потпуно индивидуалној причи која може постати обавезујућа за другог (читаоца/читатељку). Овакву поезију могуће је сматрати за иновативном, енергичном, понекад такође духовно луциднијом. У ову непосредност спада и стављање акцента на оралност, на перформативну раван (која посебно излази на видело приликом јавног читања), која често долази из боемског, односно контракултурног социјалног миљеа који измиче академској апропријацији, рецимо, у неки високошколски семинар. Јасно је да је настанку такве песничке поетике највише допринела „нова“ америчка поезија 50-их и 60-их година $\mathrm{XX}$ века у својој богатој разгранатости на различите песничке токове, као што су Сан Франциско ренесанса, њујоркшка школа, Black Mountain Poets итд.

Као што ћемо видети, америчка поезија снажно је утицала на новију словеначку поезију, посебно крајем осамдесетих и почетком деведесетих година прошлог века и тако допринела преласку из „куване“ песничке парадигме у „сирову“. Погледајмо изблиза како се то одиграло.

\section{Осамдесете године и почетак нове поетике свакодневице}

У словеначком књижевном простору након снажног потреса неоавангарде у другој половини шездесетих и почетком седамдесетих година XX века, стање се стабилизовало, тако што су се песници млађе, односно друге послератне генерације (рођени углавном крајем четрдесетих и почетком педесетих година), као што су Милан Деклева, Иво Светина, Борис А. Новак и Милан Јесих већ током друге половине седамдесетих вратили умеренијем модерниз- 
му својих претходника и тиме одбацили експерименталну поезију као нешто што је довело словеначку поезију у слепу улицу. Таква ситуација даје основни тон и касније, кад на сцену ступа такозвана генерација осамдесетих.

Ипак, у оквиру словеначке неоавангарде јавио се један од најоригиналнијих и најважнијих словеначких песника друге половине XX века који представља изузетак, а то је Томаж Шаламун. За разумевање ситуације у осамдесетим и деведесетим, међутим, важно је направити дигресију и образложити изузетан Шаламунов утицај који се осећао и у време када је неоавангардна поетика у Словенији била потиснута у позадину. Као што ћемо видети, управо је његова поезија била најснажнији катализатор нове поезије у Словенији која је направила прекретницу с доминантном модернистичком.

\section{Томаж Шаламун и „сурова поезија“}

Томаж Шаламун, кога словеначка књижевна историја повезује са словеначком неоавангардом, односно ултрамодернизмом, оригиналан песнички пут започео је чувеним првенцем Покер (1966) који је својевремено подигао велику прашину. Шаламун је на почетку сарађивао с неоавангардном групом OXO, a седамдесетих година писао је песме пре свега под утицајем америчке поезије, чак је и сарађивао с групом тзв. Language Poets. Реч је о песнику који је својим протејским песничким говором утицао на генерације каснијих словеначких песника, па и на песнике који су у центру наше пажње.

Било да интерпретирамо Шаламунову поезију у духу ОХO peизма у којем „речи читају саме себе“ (Brejc 2011: 942) или да из бесконачно метонимичног тока речи разаберемо чуђење над питањем зашто постоји свет, како каже Алеш Дебељак, ${ }^{5}$ као сигурно важи бар то да је реч о де(кон)струкцији традиционалног песничког језика (чак „умерено“ модернистичког), који је у изрицању метафизичких питања заобишао људску „физику“ и повампирио се, како пише Шаламун у песми „Химна светске одговорности“:

Доносимо љубав и слободу без мржње.

А ти, повампирени језиче,

Који си издао тело од страсти да би населио

Непознате земље,

Забрљао си! (2011: 294)

5 Дебељаковим речима казано, у Шаламуновој поезији се „херметизам модернистичке традиције сусреће с постигнућима уличне културе и емпиријским земаљским подацима како се не би укинуло оно страшно 'зашто' света него да би га вратио као питање - свет као питање, накнадно“ (1988: 87). 
Управо је Шаламун нападао надовезивање метафизичког на националну узвишеност традиционалне словеначке поезије, то јест, ако употребим израбљену синтагму Душана Пирјевца, „прешерновску структуру“б огромног дела словеначке поезије:

На тебе се, дакле, ослањам

национални вампире.

Чекај само да се довољно усијам.

Једном ћу те срушити. (2011: 344) ${ }^{7}$

Упркос томе Шаламунова поезија у целини гледано није тако монолитна као што се можда чини на први поглед. Од самог почетка у њој заправо преовлађују два типа, два усмерења, у којима се његов песнички говор могао размахнути. Први тип је очигледнији, то је надреалистичка, фрагментирана поетика у којој се ради о јукстапозицији појединачних песничких изјава. Песнички говор тежи дехијерархизацији свих дискурса и својом алеаторичношћу опире се хомогенизацији у целовиту, органску песму. Јанко Кос поводом Шаламунове (ране) поезије говори, поред осталог, о томе да се његов песнички говор угледајући се на надреалисте одева у неки одрастао „инфантилизам“ који својим језичким играма изриче нихилистичко стање савременог света. Чинећи то користи и „попартистички“ ready-made који налазимо у разним дискурсима који нас окружују (1969: 337-340).

Други тип Шаламунове поезије је мање захтеван и он је подстицај очигледно добијао из америчке поезије педесетих и шездесетих година XX века, коју поједностављено можемо назвати поезијом beat генерације, премда је ипак главни Шаламунов узор тзв. њујоршка школа (New York School) с Френком O’Харом на челу. Заједно с Џоном Ешберијем, Кенетом Кохом и Џејмсом Скајлером он важи за зачетника овог утицајног песничког покрета. За песнички језик припадника ове школе карактеристично је остајање на површини искуства савременог урбаног човека, чему се придружује ништа мање карактеристична песничка каталогизација ових или оних personalia које је посве разумљиво само уском боемском друштву, односно елитној књижевној côterie. ${ }^{8}$

6 У питању је теза да се основна структура словеначког националног постојања формирала на основу Прешернове поезије. А то значи да она има кључну улогу за словеначку народну (само)свест.

7 Реч је о песми с почетним стиховима „Буба лази нешто тражи“ из књиге Meйоga анђела, 1979.

8 Погледати: Марџори Перлоф (Marjorie Perloff 1977) и Шо (Shaw 2006). Шо наглашава (6) да кад је реч о côterie, кружоку, ужој књижевној групи, увек је у питању преплитање друштвеног и књижевног, и сматра да би требало у „позитивном“одређењу књижевне групе биографске детаље схватити као посебну врсту интерпретације која премошћава дискрепанцију између биографских детаља и реторике, и последично, естетике (теорије) или, другим речима, између живота и текста (књижевности). 
Словеначка јавност - највероватније и сам Шаламун - упознаје се с овом новом поезијом нарочито од 1963. па надаље, кад поједине битничке песме преводе Нико Графенауер и Март Оген. ${ }^{9}$ У том смислу је врло значајан последњи број Персиекииива (година IV, 1963-1964), у коме је савременој америчкој поезији посвећено много простора, а поред осталог преведени су и одломци Гинзберговог Урлика и „песма“ Френка О’Харе. И у Шаламуновим песмама написаним пре Покера евидентан је утицај њујоршке школе, што важи и за поједине песме објављене у периодици. Такав је случај с циклусом „Рибе“, који је објављен 1965. године у студентском часопису Трибуна. Реч је о песмама: „Niniche“, „Кенгуру“, „Погреб“ и „Смрт на ч“. Манир њујоршке школе најочигледнији је у песми „Погреб“с уводним стихом: „Кад је умирао Павле, ошишан на четку / наводно, није могао ни да бекне...” (Šalamun 1965: 7).

Свакодневно искуство (које је често готово репродукција дневничког записа) одувек је присутно у фрагментима као један од главних извора Шаламунове асоцијативне песничке композиције. Упркос томе, Шаламунов лични, понекад чак приватан I do this, I do that - како је маркантно поетику Френка О’Харе описао његов њујоршки колега Тед Бериган (Perloff 1977: 178, Shaw 2006: 42) - осамостаљује се у наративно компоновану песму. Такви „охаризми“ су код Шаламуна, на пример, каталози дневних активности, набрајање различитих (микро)локација, личних имена која су у потпуности разумљива само унутар његове личне côterie, као и тематизација пријатељства и љубави, укључујући хомосексуалну.

Иако њујоршка школа на први поглед има изразите антимодернистичке карактеристике, ипак је дубоко повезана с европском авангардом на коју се, иначе, надовезује Шаламунова поезија. Потребно је, наиме, нагласити да се у случају поезије Френка О’Харе заправо ради о једном од начина пресађивања европске авангарде на подручје послератне америчке поезије. Зато Марџори Перлоф у вези с О’Харом с правом скреће пажњу на авангардистичку песничку традицију, посебно на Аполинера и Мајаковског које је О’Хара сматрао великим узорима (xiii). ${ }^{10}$

Овај други тип Шаламунове поезије заузима највидљивије место у збиркама које су настале седамдесетих и у првој половини осамдесетих година. Више таквих песама можемо наћи већ у збирци Америка (1972), а након тога још чешће, све до збирке Балаgа за

9 Занимљиво је да је Оген критички иступио против Графенауерових превода замеривши да је очигледно да Графенауер ни језик не познаје довољно, а пре свега узнемирио га је његов негативан суд о овој поезији, коју је означио као декадентну појаву. Погледај Ogen 1965: 1183-1188.

10 У вези с тим треба узети у обзир дело Марка Силверберга The New York School Poets and the Neo-Avant-Garde Between Radical Art and Radical Chic (2010) у којем њујоршку „поетику процеса“ аутор повезује и с оновременим апстрактним експресионизмом (9-34). 
Мет̄ко Крашовеи (1981). Чак и насловна песма садржи препознатљиве карактеристике њујоршке поетике. У другој половини осамдесетих и деведесетих, што је занимљиво, таквих песама је мање. ${ }^{11}$

На утицај Френка O’Харе на Шаламуна скрећу пажњу поједини етаблирани амерички књижевници. На пример, Едвард Хирш у предговору („Foreward“) за избор Шаламунове поезије, коју је уредио Чарлс Симић, закључује: „I also hear something of the improvisatory delight and dailiness of the New York Poetst in these lyrics [Чујем у овим песмама и нешто од импровизаторских сласти и свакодневице песника из Њујорка]“ (2000: хіi). До сличног закључка долази и Кевин Харт који је утицај Френка О’Харе уочио и у Шаламуновој познатој песми „Балада за Метку Крашевец“ (2011: 960) и тврди да је за Шаламуна карактеристично својеврсно анти-искуство, то јест, да песма „није толико одраз искуства колико покушаја да нас током чина читања изручи оном што искуству измич““ (2011: 962).

Шаламун је својом поетиком створио читав низ епигона. Код неких младих песника који су под његовим утицајем почели да пишу крајем шездесетих и почетком седамдесетих можемо наћи и дистанцу спрам чистог неоавангардистичког лудизма (повезаног с групом ОХO), смештену у више у „веристичку“ област њујоршке поетике. Један од таквих песника који су наступили у седамдесетим је Миха Аванзо. Он није познавао америчке битничке песнике из прве руке већ преко превода објављених у Персиекииивама и Трибуни, те је стога више на њега утицао Шаламун својом дводелном поетиком (Divjak 2019: 110-111) и у седамдесетим је објавио три песничке збирке: Pravica skazica ([Наравоученија] 1973), Deklice ([Девојчице], 1975) и Marnje ([Измишљотине], 1978). Поменимо, на пример, песму „Моји путеви“ из збирке Pravica skazica, која потпуно у маниру њујоршке школе арбитрарно наводи песникове узоре (на пример, Томажа Шаламуна и Чарлија Паркера Бирда) и на крају понуди мали каталог љубљанских улица (1973: 24).

Сличну поетику можемо пронаћи и код песника који су се формирали седамдесетих, рецимо код Андреја Брвара, Изтока Осојника и тако даље. Словеначки књижевни историчар Борис Патерну је поезију седамдесетих година повезивао с „динамичним реализмом“ (1989: 218-219) у који је убројао и zamejske тршћанске и корошке песнике који су тада почели да објављују.

Ако се може рећи да су седамдесете године у словеначкој поезији бурне, стиче се утисак да ситуација на почетку осамдесетих ипак није тако живахна. Такозвана генерација осамдесетих, која је почела да објављује у осамдесетим, први пут се групно представила 1982. године у Песничком алманаху млаgих. Ова публикација била

11 О утицају америчке поезије на раног Шаламуна, укључујући њујоршку школу, видети Ђурић 2019, посебно стр. 141-143. 
је пре свега реакција на ситуацију да је у то време било тешко издати песнички првенац, будући да су велики издавачи избегавали објављивање песника који тек почињу. ${ }^{12}$ Мали број песника који су у поменутом алманаху објавили своје песме успешно су наставили песничку каријеру. Само тројица од њих су на битан начин формирала словеначку поезију те деценије - Алеш Дебељак, Јуре Потокар и Бране Мозетич.

Као одговор на овако незавидно стање у издаваштву, 1985. године оснива се издавачка кућа Aleph, коју на почетку воде Андреј Блатник и Владо Жабот, која је објављивала пре свега песничке првенце. Све до средине осамдесетих година важну улогу играо је копарски издавач Лити $а$, који је својом едицијом „Роб“ бринула за издавање неетаблираних песника. Крајем деценије, 1989. године, из часописа

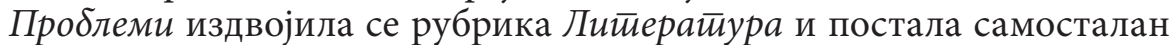
књижевни часопис који су прве године уређивали Јани Вирк и Вид Сној. Његов значај био је велики будући да је ускоро постао најважнији словеначки књижевни часопис у којем су објављивали своје песме и они који су се појавили деведесетих година.

Међутим, најважнији документ књижевне генерације осамдесе-

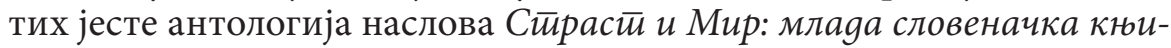
жевности (1990), коју су уредили Недељко Радловић и Јани Вирк, а на српски превео Војислав Деспотов за оновремени југословенски простор. Била је то трећа књига едиције „Савремена југословенска књижевност" коју је основала књижевна група у Кикинди у намери да се стане на пут конструисању неке заједничке (свакако непостојеће) југословенске књижевности и да се уместо тога појединачне националне књижевности представљају самостално. Ова интенција уредника у Post scriptumu образлаже се следећим речима: „Будући да постоје само националне културе и унутар њих свакако само појединци који у самоћи, еуфорично или меланхолично, надахнути божјом искром или незаустављивом жељом за артикулацијом, пишу своје текстове“ (Virk 1990: 225).

Као најрепрезентативнији словеначки песници и песникиње деценије за антологију су изабрани: Алеш Дебељак, Маја Хадерлап, Алојз Ихан, Горан Глувић, Раде Крстић, Фери Лаиншчек, Бране Мозетич, Јуре Потокар, Штефан Ремиц, Маја Видмар, Милан Винцетич, Алдо Жерјал и Бране Битенц. Занимљиво је да од свих ових песника само Горан Глувић и Бране Битенц у својој поезији посежу за „нижим“ регистрима, полазећи од спонтаног говора који се приближава обичном, којим говоре о мање-више тривијалним темама, те тако подсећају на оно што смо полазећи од Ловела провизорно назвали „сирова“ поезија. Код Глувића су у питању најчешће брехтовски друштвено-критички тонови (којим је узор делимично могао бити и

12 Погледати увод „Zagovor in pojasnilo“ [Увоg и обjauюеґе] y Berger, Mušič et al. 1982: 5. 
Ервин Фриц $\left.{ }^{13}\right)$, а код Битенца се пре ради о панк сензибилитету који је усмерен на тинејџерску делинквенцију (није згорег поменути да је овај песник оснивач и текстописац прилично успешне панк групе Otroci socializma [Деца социјализма]). Ипак, ова поетика ни у корпусу ових песника не долази до изражаја. Код Битенца је још увек очигледна осцилација између рафиниране егзистенцијалистички интониране лирике (можда по узору на Алеша Дебељака) и свакидашње "сиве“ стварности која се понекад чак граничи с вулгарношћу што се лепо види у јединој збирци коју је издао Kri ([Крв] Марибор: Обзорја, 1986). ${ }^{14}$ Мало пре него што ће потпуно ућутати као песник, Битенц је писао и сонете у вишем исповедном регистру ${ }^{15}$.

Сличан Битенцу или бар упоредив с њим је Есад Бабић, такође припадник „генерације осамдесетих“, а који се крајем осамдесетих јавио пре свега као текстописац панк групе Via ofenziva. Иако најчешће није био уврштен у касније антологије ${ }^{16}$ и књижевноисторијске прегледе, још осамдесетих је издао чак три збирке песама. Након првенца Кавала (1986) објавио је Malemu boksarju ([Малом боксеру] 1988) и Angel sscufanimi krili ([Анђео офуцаних крила] 1989). И у његовој лирици може се уочити дилема да ли да крене „углађеним“ лирским путем (уз сублимирану рилкеовску рефлексивност) или да у пригодним песмама уведе принцип анегдоте, можда чак с панкерском сировошћу која не преза од описа бруталнијих аспеката „свакодневице“, као што је случај, на пример, у песми „Заклан“ из прве књиге (1986: 30).

Треба поменути и Алојза Ихана који се својом оригиналном поетиком највећма истицао међу песницима те генерације и који је својим првенцем Srebrnik ([Сребрњак] 1986) такорећи преко ноћи постао славан, будући да је поред осталог примио југословенску награду „Горан“ за младе песнике. Ихан је у то време био врло омиљен и у најширем кругу читалаца, код људи који се иначе не интересују за књижевност, а не само код елите упућених, што је постигао „чврстом и прегледном песничком причом коју, по правилу, закључује снажна поента“" (Virk 1990: 14). У питању је врста наративне поезије која је у дотадашњој словеначкој поезији била ретка; упркос томе се чини да његов утицај на каснију словеначку поезију, која је држала

13 Ервин Фриц (1940) је словеначки песник, драматург и драматичар. Његова дела се одликују изразито реалистичном поетиком и друштвеном ангажованошћу.

14 Исте године у издавачкој кући FV излази истоимена музичка касета поменуте групе. 15 Погледати песму „Страст и мир“ објављену у првом броју Литературе 1989 (1/1, стр. 13-14).

16 Уврштен је у антологију много касније, и то у антологији Јосипа Остија У јанйару времена: анйолоіија словеначке йоезије (1950-2000). У уводној студији „О савременој поезији“, Ости о њему пише: „Мада живот доживљава прије свега као партију отвореног покера, коју игра са страшћу радозналог, осјетљивог и наивног вјечног дјетета, своју пјесничку пажњу усредсређује углавном на рану" (2006: 35). 
свакодневицу и неметафизичност за две основне матрице, није био велики, вероватно стога што се код Ихана свакодневни језик ипак често исцрпљује у параболичности.

Можемо се сагласити с оним што је рекао Матевж Кос: „Осамдесете године засигурно нису биле више време нерефлектованог оптимизма који се темељио на тврдоглавој вери у Напредак уметности до кога би саморазумљиво, такорећи аутоматски требало да доведе 'смена' књижевних генерација и предност биолошких карактеристика младог нараштаја“ (1990: 96-97). Постепено се успоставило стање које је тешко књижевноисторијски прецизно одредити и ставити му јасну еволуцијску етикету. Зато Јани Вирк обазривије говори о „полифонији аутопоетика“ које се не подређују развоју, односно ма којој телеологији. Вирк се, што изненађује, опире и етикети „постмодернизам“ (1990: 8) која је у то време свеприсутна у критичком и научном дискурсу кад се говори о најновијој уметности и књижевности.

Поставља се питање да ли је крајем седамдесетих и касније, у осамдесетим годинама, у Словенији могуће говорити о песничком постмодернизму. На ово је прво покушао да одговори познати словеначки филозоф Тине Хрибар. По његовом мишљењу, постмодернизам је у основи одговор на то како уопште превазићи језичку виртуозност песничког модернизма, покушајем да се заобиђе телеолошки схваћен књижевноисторијски напредак и да се нађе „пут који је другачији од већ постојећих“ (Hribar 1984: 230). Ако по Хрибару многи словеначки модернисти већ показују елементе постмодернизма (на пример, Светлана Макарович и Томаж Шаламун), за њега је „окидач“ песничког постмодернизма поезија Вена Тауфера од средине седамдесетих година надаље (Hribar 1984: 259). Tауферу се придружују млађи песници као што су Иво Светина, Милан Јесих, а пре свега Борис А. Новак, кога Хрибар сматра централним представником постмодернистичког песништва у Словенији (Hribar 1984: 269). Хрибар истиче два кључна услова за постмодернизам: поступак палимпсеста који избегава „савршеност“ модернистичке естетике (Hribar 1984: 245) и поступак „хагиопоетизације света“ (Hribar 1984: 257). Притом се највише ослања на филозофију Мартина Хајдегера: „Док је протомодернистички период дефинисан егзистенцијалном тематиком, а модернизам се креће у простору онтолошке диференције, постмодернизам почива на искуству о светости света (Hribar 1984: 257). Упркос важности и оригиналности Хрибарове рефлексије о песничком постмодернизму у Словенији, треба рећи да је њен суштински недостатак у томе што се током интерпретације књижевних текстова често готово аксиоматски ослања на хајдегеровско разумевање онтолошке диференције и светог и света. Зато је са становишта књижевне историје (на шта скреће пажњу пре свега Матевж Кос, 1996: 127-139) проблематична у оној мери у којој захтева пристанак на одређено филозофско усмерење: 
хајдегеровско поимање историје. У сваком случају, Хрибар је ипак први у Словенији прецизно указао на основни елемент постмодерне епохе, на њен унутрашњи плурализам. Одатле и његова теза да се постмодернизам састоји од „коегзистенције различитих песничких усмерења" (Hribar 1984: 279), од тежње за тзв. аутопоетикама.

Да поезија у осамдесетим (и касније у деведесетим) није имала ништа заједничко с постмодернизмом, јасно је доказао Матевж Кос у чланку „Савремена словеначка поезија и питање постмодернизма“ (1996: 78-173). Његову тезу прихватио је и Јанко Кос, који постмодернистичку релативизацију истине и стварности песничких доживљаја, као основно категоријално одређење постмодернизма у смислу посебног књижевног смера, проналази само у „маниризму“ Милана Јесиха (2000: 389), док друге ауторе, на пример, Тауфера, Светину и Новака смешта или у модернизам или у постсимболизам. Истини за вољу, књижевна критика, па чак и понеки књижевни историчар, овом етикетом служио се и након 2000. године. ${ }^{17}$

С друге стране, чињеница је да је то још увек време кад млади песници тешко доспевају у центар пажње будући да најпознатији и најомиљенији аутори осамдесетих година још увек долазе из редова тзв. умерених модерниста. Тада своје најзначајније збирке издају Дане Зајц (Zaprotitive [Врачке], 1985), Грегор Стрниша (Vesolje [Свемир] 1983), Вено Тауфер (Tercine za obtolčeno trobento [Терцине за улубљену трубу], 1985), Нико Графенауер (Skrivenosti [Тајне] 1983, Палимйсестии 1984, Izbrisi [Брисања], 1989), Кајетан Кович (Dežele [Земље], 1988). Од песника који су почели да објављују осамдесетих на видно место су се пробили само Дебељак, Потокар, Хадерлап и Ремиц. Вирк их одређује као оне „које карактерише формална дисциплина и интелектуално изузетно прецизан речник“ (Virk 1990: 9). Владајући укус времена био је недвосмислено на страни „високе“, „куване“ поезије.

\section{Касне деведесете као преломна тачка}

Овде нећемо моћи шире да обрадимо све песнике деведесетих година, па ћемо се зато посветити песницима који су своје првенце издали након 1990. године. По узору генерације осамдесетих, прови-

17 Погледати Poniž 2001, посебно поглавље „Postmodernizem se uveljavi [Постмодернизам се устоличује] (1985)“ (311-327) или Kolšek 2006: 622-642. Јанко Кос у књизи Primerjalna zgodovina slovenske literature [Компаративна историја словеначке књижевности] (2001: 389-390) сматра само Милана Јесиха (Сонейи 1989) за песника који се највише приближио песничком постмодернизму у Словенији. Пре тога, у књизи $\mathrm{Na}$ poti v postmoderno [На путу у постмодерну] (1995) долази до закључка да је преузимање америчких матрица својеврсна словеначка специфичност словеначке постмодерне (не постмодернизма као посебног смера унутар ње). Иако је истина да је и у другим европским књижевностима деведесетих година дошло до преовладавајућег утицаја америчке поезије, најочигледнији случај је пољски. 
зорно ћемо их назвати „генерација раних деведесетих“, иако је потребно скренути пажњу да између првих и других у суштини нема разлике. Упркос томе, можемо рећи да тада „сирова“ поезија почиње да утире свој пут полако излазећи из маргине, где су је потиснуле касне седамдесете, а још очигледније осамдесете. Једини који је све време више-мање истрајавао у таквој поетици био је Томаж Шаламун. Ипак, потребно је поменути песнике који су се посвећивали социјалним, односно друштвено-критичким темама, иако су њихове аутопоетике, у суштини, прилично различите. Највише су се истицали Ервин Фриц (1940), Тоне Кунтнер (1943) и Андреј Брвар (1945).

У наставку ћемо се кратко посветити шесторици песника који су објавили своје првенце 1991, дакле оне године кад се распала Југославија и словеначке самосталности. То су: Бране Сенегачник, Вид Сној, Миклавж Комељ, Петер Семолич, Јуриј Худолин и Урош Зупан. Избор године 1991. не говори у прилог томе да је та година некакав књижевни annus mirabilis, премда је чињеница да је те године своју песничку каријеру почело много нових имена. Избор је, ипак, бар у некој мери арбитраран, будући да бисмо могли узети и 1990. годину и додати песнике као што су Марјан Стројан, Матјаж Пикало, Новица Новаковић. Последњи наведени, узгред речено, за свој првенац Raztegljiva tetovaža [Еластична тетоважа], као последњи у Југославији примио је награду „Горан“ за младе песнике. Списак се може још проширити. За 1991. годину потребна нам је, пре свега, нека врста књижевноисторијске сондаже помоћу које бисмо проверили хипотезу да је на почетку деведесетих словеначка поезија на међи две тенденције, то јест, „високе“, „куване“, на једној, и „ниске“, „сирове“ поезије на другој страни. Са становишта развојно конципиране књижевне историје може се уочити померање с подручја модернистичке поезије с егзистенцијалистичким темама, што све налазимо код Данеа Зајца, делимично код Ника Графенауера, ка антимодернистичкој поезији, која игра на свакодневни говор у намери да избегне велике приче европске метафизике. Њен врхунски узор у домаћим условима је Томаж Шаламун, а поред њега, америчка поезија beat генерације, али и друге послератне тенденције у Америци.

Бране Сенегачник (1966) се својим песничким првенцем Srčni $g r b$ (Гр $\delta$ сриа, 1991) јасно поставио као наследник европске традиције (нео)романтизма и симболизма који у словеначкој поезији налазимо код Мурна и Градника. Упркос томе, његово песништво обогаћено је искуством модернизма, где му је, у словеначкој поезији, пре свега био узор Нико Графенауер, а од страних песника, поред француских симболиста, као што су Бодлер, Маларме и Верлен, свакако Рилке, можда и Готфрид Бен. Његове песме, писане у густом и узвишеном тону, представљају експресије индивидуалне интиме које покушавају да искажу вишак, односно неизрециво у 
смислу традиционалне (позитивне) трансценденције. Значајно за ове песме јесте и то што је у њима много референци из „високе“ културе, на пример, из класичне музике и античке митологије.

На стилској равни, у Srčnom grbu истичу се раскошне, на моменте сасвим декоративне генитивне метафоре као што су „краљевско цвеће ћутања“, „озвезданост плаветнила“, „свилени залазак речи“, „вечни пулс стакленог срца“, „усамљено лебде руже невремена“, „оригинално цветање пролазних, јединих ствари“. Таква језичка згушњавања су покушај песничког изрицања оног што измиче песничкој слици, зато су често уоквирене рилкеовском рефлексивношћу у смислу својеврсне песничке онтологије која покушава да изрази какве су ствари по себи у духовном смислу речи. Ипак, овде Апсолут, као последња референца Сенегачникове лирике није (класична) симболистичка „празна“ трансценденца (у смислу Метерлинковег néant hostile) већ је реч о Апсолуту који захтева веру и зато је „пун“, позитиван, иако као „ништавило“ свакако делује „апстрактно“, као што је очигледно у песмама „Torek 18. 9. 1984, ob 21:50, pars tertia“ [Уторак, 18. 9. 1984. године, у 21: 50, pars tertia]:

Веровати у тебе,

плешуће ништавило,

дубоки простор ствари. (1991: без пагинације)

Вид Сној (1966) је првенцем List in sen (Листи и сан, 1991) храбро ушао у поезију с високо култивисаним језиком у којем је приметан утицај умереног модернизма Ника Графенауера, а у још већој мери једног од највећих песника немачког модернизма Пола Целана. Овај утицај је приметан у крајње згуснутим стиховима који, естетски ишчишћени и с изненађујућим метафорама, делују веома свеже:

Из високо кликтавог мука,

кроз своје си, од година вијугаво,

тело кренула,

кошничава. $(8)^{18}$

Или:

Дођи,

листом аканта излистана,

ступна. (15)

Упоредимо и овај одломак из исте збирке:

У сну помраченом: свака реч је ружа подземљена, свето противречје

- пословица. (48)

18 Одломке Снојевих песама на српски је превео Милосав Гудовић. 
У Листи $y$ и сну чести неологизми уводе језик у највише естетске регистре, чинећи га истовремено ирационалним, семантички затамњеним. Слично дејство имају богате, зачудне (неретко генитивне) метафоре које показују специфичан сензибилитет, као што су „ризомски међупростор који зараста“ (11), „од хиљадуструке тајне утрљане / попут каменца“ (20), „многооблична крилата олуја / на слепоочницама" (37).

На позадини Снојеве песничке херметичности може се наслутити преплетање еротског и духовног које на захтеван, али оригиналан начин, почетком деведесетих, оживљава романтично-модернистичку поетику изрицања неизрецивог. Будући да је то једина збирка коју је Сној објавио, словеначка поезија остала је ускраћена за могућност развоја у овом смеру.

Миклавж Комељ (1973) ступио је на сцену словеначке поезије као Wunderkind, будући да је тек напунивши осамнаест година објавио књигу Луч gелфина (1991), која је и формално и садржински, имајући на уму да је у питању првенац, изузетно захтевна поезија. Збирка је углавном сачињена од класичних сонета које је у словеначки простор поново увео Борис А. Новак у позним седамдесетим, премда је у тим песмама, упркос наизглед традиционалном симболистичком језику, пуно фриволности и ироније. Тако, рецимо, песничко ја традиционалној теми смрти одузима озбиљан егзистенцијалан набој и обраћа јој се опуштено, као да је његова (свакодневна) љубавница:

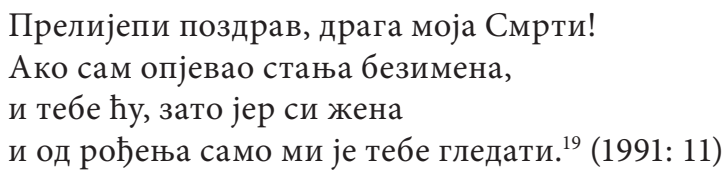

Чини се као да песнички субјект метафизику све време деконструише с некаквом инфантилном обешћу, ироничним тематизовањем „тешких“ или „високих“ тема. Тиме можда указује на крај метафизичке струје словеначког умереног модернизма. Зато се рефлексивност окреће сама у себе, у неку врсту делиричне саморефлексије, при којој се лирско ја доживљава као извориште тока вербалне материје:

Али један што иступа, иступа. Једини немогуће луд све време. И то је баш онај који сам ја. (25)

У овим песмама је прегршт традиционалног; преовлађује, пре свега, уобичајен речник, често прошаран потпуно декоративним метафорама које деградирају неке песме, што се понегде дешава ус-

19 Хрватски превод Ксеније Премур и Милоша Ђурђевића у Kos 2006: 42. 
лед експлицитне религиозне поенте, све до равни патетике. Овде још увек не проналазимо истинску спонтаност и продор у свакодневицу. Ни каснија Комељева поезија није ишла у том смеру, бар до збирке Роса (2002), након које је Комељ постао један од најпознатијих оригиналних гласова у савременој словеначкој поезији.

Прелаз у неметафизичко је опипљивији код Петра Семолича (1967) који је своје песме објављивао у часописима још од средине осамдесетих, премда је своју прву збирку с насловом Тамарища објавио тек 1991. године (при крају књиге сазнајемо да је била написана још 1984. и 1985. године).

Овај првенац открива нам песника идиосинкратичних тензија, чак песника еклектицизма. Кад Семолич посеже за „високим“регистрима, у томе се не може превидети утицај Данеа Зајца, пре свега имајући на уму тамну, неретко анималну метафорику. Већ на почетку збирке, у песми „Балада о мочвари“, срећемо овакве зајчевске стихове:

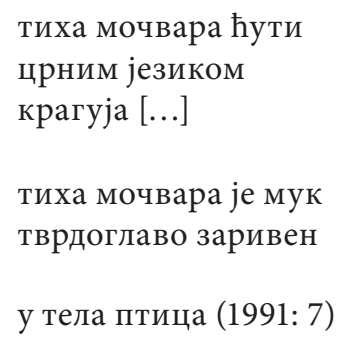

Семолич је оригиналнији кад се његова поезија уздиже до светлијих тонова у којима се јављају женски ликови. Тада лирски субјекат ослушкује „шапат наранџастог ветра / и сањам девојке / од мака“ (23). Идући ка крају књиге песнички диктус постаје релаксиранији, игривији, чак еротичнији, тако да у последњој песми „Кишобран нема носталгију“ можемо прочитати стихове који су, неочекивано, стављени у уста кишобрану:

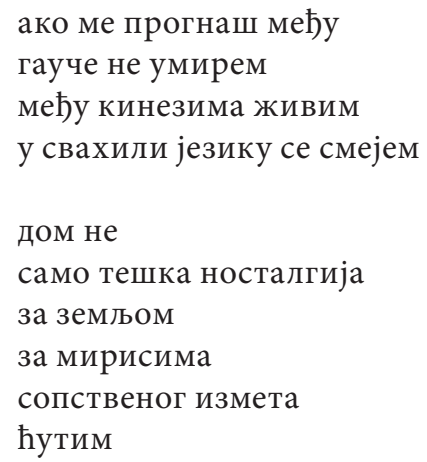


Овако опуштени, хуморни тонови у поезији с почетка деведесетих били су прилично ретки. Како год било, Семолич се током деведесетих својим збиркама прославио као мајстор поезије наглашене лиричности у чијим рефлексивним и емотивним констелацијама преовладава меланхоличан хабитус (Kos 2003: 211).

Јуриј Худолин (1973) био је деведесетих прилично познат песник на словеначкој песничкој сцени, премда након 2005. године пише углавном прозу. Својом првом збирком песама Če je laž kralj (Aкo je лаж краљ, 1991) покушао је да крене оригиналним поетским путем, неком врстом неодекадентне оргијастичности која би да освоји своје место под сунцем пре свега естетиком ружног (Poniž 2001: 319-323). Упркос томе, његова рана поезија у много чему је дужник Зајчеве, пре свега певањем о тамним силама света које су знак одсуства Смисла. У овај зајчевски метафизички оквир улазе елементи који се понекад ослобађају традиционалних егзистенцијалних тема и продиру у подручје свакодневице. Таква је, на пример, последња песма из књиге Ajdbog in ptičvolkkača (џинбоі и йтиицавукзмија, 1992) с насловом „Једна обична песма“:

\author{
Тако увече размишљам \\ о метафорама \\ све даље и даље мислим \\ ооо јуриј how do you do \\ тако палим цигарету цигаретом \\ и метафору метафором \\ па тиме ломим главу \\ па сам од метафора опијен \\ уф какво самогиљотинирање \\ то је једна обична безвредна песма (50)
}

Очигледно је да се таква поетика свакодневице у то време, уколико се уопште јавља, налази на маргини неког песничког дела, можда на последњој страни збирке, као додатак, као што је случај у Худолиновој књизи.

Погледајмо још Sutre, првенац Уроша Зупана (1963). Овде је индикативан већ сам избор наслова који не алудира на будистичку духовност или филозофију него пре свега на поезију Алена Гинзберга (сетимо се само његових познатих песама као што су Sunflower Sutra, Wichita Vortex Sutra итд.). Дотични песник је главни Зупанов песнички ментор и у песми „У Америку!“, објављеној

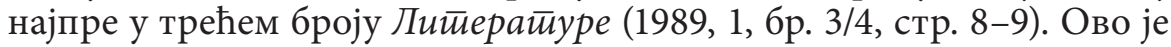
очигледно и на нивоу форме, будући да се дугим стихом очигледно угледа на Гинзбергову поему Howl, иза које стоји наслеђе валовитог ритма Волта Витмана. Насупрот Гинзбергу, Зупан (или, боље, лирски субјекат те песме) енергично прозива себе савременим бардом 
који се из (забитог) словеначког Трбовља са „словенским шармом“ намерачио да освоји Америку. На крају, не успевши да се задржи, помиње своје битничке узоре (Џека Керуака) и легенде џеза (Бирда - Чарлија Паркера, Кирка - Роланда Кирка):

Крећем у град анђела и чекам да се затресе тектонска прекретница,

обилазим ноћне локале да оњушим howloвски или или лама

савахтани саксофонски крик, пробудим Џека Керуака, Бирда,

Кирка,

препун музике, препун енергије,

Америко, ДОЛАЗИМ! ${ }^{20}$ (1991: 10).

Целокупна збирка се свесно напаја америчким покретом Сан Франциско Ренесанса (Гинзберг, Керуак) и њујоршком школом

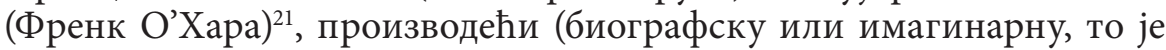
овде ирелевантно) личну причу Уроша Зупана (или његовог песничког аватара), његовог I do this, I do that. Међутим, треба додати да Зупан ово чини на свеж, енергичан начин који је оплођен Шаламуновом експлозијом језика, иако без неоавангардне алеаторике. ${ }^{22}$ Песме су, наиме, исписане наративно и пре свега читљиво, крцате неочекиваним песничким јукстапозицијама.

За разлику од својих америчких битничких узора са западне обале северноамеричког континента, Зупанова поезија је без битничке еклектичке религиозности, њуејџ мистицизма (какав су неговали посебно Гинзберг и Керуак); његов свет би да је свет љубави, очишћен од сваке метафизике, љубави свакодневне и стварне, какву опева посебно у циклусу „Сутре“, премда се управо та поезија изнова романтизује и улази у неку рафинирану интимност која није само интимност приватне површине него и егзистенцијалне дубине: на задња врата ове поезије изнова улази метафизика љубавног споја, два срца, две душе:

... да ћемо

као свет око нас у киши - чиста душа - сами

и питам се - да ли ћемо се уплашити, или ћемо се

још више зближити кад не буде ничег да се скрива.

Ох, небо и пакао заувек скупа, никад одвојени (1991: 23).

20 Превео Милосав Гудовић. Упоредити хрватски превод у Кос 2006: 8.

21 Песма „Све што ме подсећа на тебе“ посвећена је Френку О’Хари и у њој, поред осталог, читамо: Нјујоршка песничка школа гори у мом џепу /док крочим Менхетном, / као некад ти, Френк... (13)

22 Шаламунов утицај истиче и Матевж Кос (1996: 67). 
Уместо метафизике - „и ја напуштам метафизику“ (24), двапут тврди лирски субјекат у песми „Ноћне сутре“ - долази метафизика срца, односно, као што се каже у поменутој песми, „алхемија срца“ (упореди Кос 1996: 69):
и ја напуштам метафизику у покушају да из детаља
још једном у делићима саставити мозаик
који је неко већ састављао давно пре мене
не би ли пробао да састави мозаик који се зове алхемија срца (1991: 24).

Оваква алхемија срца, која је последња станица платонистичке метафизичке светлости, споја ја и $\overline{\mathcal{u}} u$-ја у једно, потпуно је овде, с ону страну времена, растерећена религиозног а ипак управо због тога његов ефектан Ersatz:

морам се оденути у круг течне светлости

и овај круг течне светлости бићеш ти (1991: 53).

Зато се упркос готово декларативној вољи за изрицањем изрецивог, свакидашњег, анегдотског, језик Зупанове поезије ипак често издиже у сублимне регистре, ојачан претежно светлим интимизмом и неоромантичарском метафориком.

у Sutrama имамо посла, дакле, са специфично аутопоетичким, зупановским начином преболевања модернизма или, речено патетично: традиционалне метафизике. Даљи развој или, радије, прича словеначке поезије, бар од краја деведесетих надаље, била је заправо Зупанова матрица успостављена у Sutrama, врло утицајна, нарочито након што је у себе, с великим закашњењем, пустила утицај америчких послератних песничких токова.

Иако 1991. године можда није настала ниједна важнија песничка књига коју би потписала словеначка песникиња, не можемо заобићи женску поезију. На преласку из осамдесете у деведесете, односно на почетку деведесетих, на словеначку песничку сцену доспева много нових песничких имена. Од мање познатих песникиња какве су Инес Цергол, Вида Мокрин-Пауер, Вања Стрле итд, до познатијих и касније етаблираних, као што су Цветка Липуш, Маруша Кресе и Мета Кушар. ${ }^{23}$ Од последњих се у касним деведесетим можда највише приближила поетици свакодневице Маруша Кресе (1947-2013). Beћ у њеном првенцу Danes из 1989. године (Целовец, Драва) налазимо једноставне песме које су сасвим утопљене у специфичну, дубоко доживљену интимност без потребе за метафизиком. Таква је, рецимо, песма „Данас“:

23 Поводом избора песама наведених песникиња погледати Трећи део антологије коју је уредила Ирена Новак Попов (2007). 
Данас не могу.

Нико не разуме да данас не могу.

Данас сам прегазила мачку

која је трчала преко улице,

и данас сам ударила у комшијин ауто.

Потом сам се саплела о степеницу

и разбила посуду за чај.

И нико не разуме

да данас не могу да скувам ручак.

Данас је небо било црвене боје... (2019: 17)

Писање Маруше Кресе је изразито женско, понекад чак феминистичко, али без друштвено ангажоване позе будући да је основа одакле долази њена аутобиографија, „бескомпромисна личност“ (Novak 2019: 118). Њен интимизам се предаје и сасвим свакидашњим искуствима а да притом не губи дубоку етичку сензибилност и поетичност.

За крај треба поменути још једног аутора који је песничко продирање у свакодневно, „сирово“ на равни кохерентне поетике извео најдоследније - то је Тоне Шкрјанец (1953). Он је већ писао у осамдесетим, али своју прву збирку успео да изда тек 1997. године (Blues zamaha); можда бисмо је могли сматрати за неку врсту антологије његовог претходног стваралаштва. Петер Семолич пише да су на Тонеа Шкрјанца, као наследника поезије свакодневице и спонтаности, утицали његови песнички вршњаци као што су Изток Осојник, Војко Горјан и Јуре Детела:

Њихова поезија је из популарне културе преузимала одређене форме изражавања, пре свега сленг, као и врсту космополитизма који се откривао у убеђењу да је сваки човек најпре грађанин света, а тек накнадно грађанин ове или оне политичке творевине, што се у песмама види као мешање различитих језика, неретко су из ње позајмљивани цитати које је неоптерећено постављала крај референци из високе културе (2008: 7-8).

У Шкрјанчевом првенцу срећемо песме у којима је аутор укључен својим личним животом, понекад чак својим конкретним телесним присуством. Тон је скоро сасвим налик говорном и готово увек зачињен иронијом и хумором. За разлику од (раног) Зупана, у Шкрјанчевим песмама преболевања метафизике „алхемијом срца“ нема више. Лирски субјект се све време држи на површини личног искуства тако да имамо осећај да се озбиљна егзистенцијална и метафизичка питања уопште не избегавају већ као да њих никада није ни било. Често су такве песме збијене чак у хаикуе, премда без зен будистичке свести о пролазности и пропадљивости свега, без wabi-sabi естетике која је карактеристична за (West Coast) битнички дискурс. У позадини Шкрјанчеве поезије Френк О’Хара и Чарлс 
Буковски пружају руке један другом, а с времена на време осетан је и утицај Герија Снајдера, од Словенаца без двоумљења Шаламуна, али без надреалистичког аутоматизма писања, без икаквог ирационализма, само са својим шармантно „словенским“ I do this, I do that. Ослушнимо крај једне такве песме:

сијеста

крај свеће издржим дуже јер она несумњиво греје ако јој приђеш довољно близу. С људима је и овако и онако. неки воле хладно пиће други радије телефонирају, ја тренутно најрадије седим крај ове лење зелене реке гледам врбе како се уморно и скептично огледају у води пијем беванду и причам глупости (2008: 83).

\section{Закључак}

Савремена словеначка поезија осамдесетих и на почетку деведесетих година доживела је развој о коме не треба нужно размишљати у широким потезима етикетирања књижевним правцима какви су (пост)симболизам, модернизам и постмодернизам. У овом чланку, служећи се појмовним паром „сирове“ и „куване поезије“, који је пре шездесет година употребио Роберт Ловел, покушали смо да детектујемо, ако не развојне (у смислу књижевноисторијске телеологије), бар појавне (феноменолошке) промене у начину писања у словеначкој поезији. Не ради се само о садржинским (мотивско-тематским) променама које долазе до изражаја у одустајању од великих метафизичких и егзистенцијалистичких тема које је оставило за собом западно песничко наслеђе од романтизма до модернизма - она у потпуности ступа у (ово)светско подручје богатих семантичких регистара који нуде свакодневна искуства у жељи за певањем о конкретном, личном и сингуларном. Нова „сирова поезија“ доноси и изразито плуралне песничке поступке (аутопоетике), све од традиционалних песничких форми преко слободног стиха и понекад чак формалног експеримента, до сасвим наративних модела у којим (изузев на визуалан начин) не можемо пронаћи линију која раздваја поезију од прозе. Иако словеначка књижевна историја до сада песничким првенцима који су настали крајем осамдесетих и на почетку деведесетих није признавала квалитет у смислу да су с књижевноисторијског аспекта епохалне, односно преломне, у њима се ипак могу пронаћи клице које неопозиво одређују чак и најновије словеначко песништво, то јест, врло продуктивно песништво које је настало током последње две деценије и које још чека на опширније компаративистичке и књижевноисторијске анализе. 


\section{ИЗВОРИ}

Avanzo, Miha. Pravica skazica. Ljubljana: Mladinska knjiga, 1973.

Babić, Esad. Kavala. Koper: Lipa, 1986.

Berger, Aleš, Mušič, Janez i Novak, Boris A. (Ur.) Pesniški almanah mladih. Ljubljana: Mladinska knjiga; Maribor: Obzorja, 1982.

Hudolin, Jurij. Ajdbog in ptičvolkkača. Grosuplje: Mondena, 1992.

Komelj, Miklavž. Luč delfina. Celovec-Salzburg: Wieser, 1991.

Kos, Matevž (Ur.) Vraćamo se uvečer. Antologija mlade slovenske poezije 1990-2003. Zagreb: Hrvatsko društvo pisaca, 2006.

Krese, Maruša. Pesmi: izbor. Novo mesto: Goga, 2019.

Novak Popov, Irena (Ur.) Antologija slovenskih pesnic 3: 1981-2000. Ljubljana, Tuma, 2007.

Semolič, Peter. Tamariša. Ljubljana: Cankarjeva založba, 1991.

Senegačnik, Brane. Srčni grb. Ljubljana: Aleph, 1991.

Snoj, Vid. List in sen. Ljubljana: Mladinska knjiga, 1991.

Šalamun, Tomaž. „Ribe“ Tribuna, 15. 16 (1965): 7.

Šalamun, Tomaž. Kdaj. Izbrane pesmi. Ljubljana: Študentska založba, 2011.

Škrjanec, Tone. Blues zamaha. Ljubljana: KUD France Prešeren, 2008 (2. izdanje).

Zupan, Uroš. Sutre. Ljubljana: Aleph, 1991.

\section{ЛИТЕРАТУРА}

Brejc, Tomaž. „Tomaž Šalamun in Julian Schnabel. Pesnik prihaja nasproti“ Kdaj: izbrane pesmi. Ur. Tomaž Šalamun i Aleš Šteger. Ljubljana: Študentska založba, 2011.940-954.

Debeljak, Aleš. Melanholične figure: eseji o književnosti. Ljubljana: Univerzitetna konferenca, 1988.

Divjak, Igor. „Danes sem volje za pesem“ Miha Avanzo. Rorschach: stare in nove. Ljubljana: Mladinska knjiga, 2019. 109-120.

Đurić, Dubravka. „Early Tomaž Šalamun and American Experimental Poetry“ Primerjalna književnost 42.2 (2019): 135-148.

Gelpi, Albert. American Poetry after Modernism: The Power of the Word. Cambridge, Mass., Cambridge UP, 2015.

Gould Axelrod, Steven. Robert Lowell. Life and Art. Princeton: Princeton UP, 1978.

Hart, Kevin. „Iz revije Verse 18.2-3, 2001“, Tomaž Šalamun. Kdaj. Izbrane pesmi. Ljubljana: Študentska založba, 2011. 955-964.

Hirsch, Edward. „Foreward“ Tomaš Šalamun. Feast. Poems, ur. Charles Simic. New York-San Diego-London Harcourt, 2000. xi-xiii.

Hribar, Tine. Sodobna slovenska poezija. Maribor: Obzorja, 1984. 175-283. 


\section{Читање традиције}

Kolšek, Peter. „V objemu dveh struktur“ Peter Kolšek, Peter (ur.), Nevihta sladkih rož. Antologija slovenske poezije 20. stoletja. Ljubljana: Študentska založba, 2006. 622-642.

Kos, Janko. „Tomaž Šalamun: Namen pelerine“. Sodobnost 17.3 (1969): 337340.

Kos, Janko. „Moderna slovenska lirika“ Janko Kos. Moderna slovenska lirika: 1940-1990. Ljubljana: Mladinska knjiga, 1995. 174-193.

Kos, Janko. Na poti v postmoderno. Ljubljana: LUD Literatura, 1995.

Kos, Janko. Primerjalna zgodovina slovenske literature. Ljubljana: Mladinska knjiga, 2001.

Kos, Matevž. „Genealogije samote“ Jute Potokar. Stvari v praznini. Ljubljana: Mladinska knjiga 1990. 93-107.

Kos, Matevž. Prevzetnost in pristranost. Literarni spisi. Ljubljana: LUD Literatura, 1996.

Kos, Matevž. „Zadnji odcep za Parnas“ Matevž Kos (ur.), Mi se vrnemo zvečer. Antologija mlade slovenske poezije 1990-2003. Ljubljana: Študentska založba, 2004. 189-221.

Novak, Boris A. „Najbolj pogumna duša je Maruša: (o etiki in življenjski poetiki Maruše Krese)" Maruša Krese. Pesmi: izbor. Novo mesto: Goga, 2019. 114-133.

Ogen, Mart. „Beat generacija in njeno mesto v ameriški sedanjosti in literaturi“ Sodobnost 13.11. (1965): 1183-1188.

Osti, Josip. „O suvremenoj slovenskoj poeziji“ Josip Osti. U jantaru vremena: antologija slovenske poezije (1950-2000). Sarajevo: Tugra, 2006. 5-42.

Paternu, Boris. Obdobja in slogi v slovenski književnosti. Študije. Ljubljana: Mladinska knjiga, 1989.

Perloff, Marjorie. Frank O'Hara: Poet among Painters. Austin: University of Texas Press, 1977.

Poniž, Denis. Slovenska lirika 1950-2000. Ljubljana: Slovenska matica, 2001.

Radlović, Nedeljko in Virk, Jani (ur.) Strast in Mir: mlada slovenačka književnost. Beograd: Književna reč; Ljubljana: Literatura; Kikinda: Književna zadruga, 1990.

Semolič, Peter. „Tisto pravo, kar predaš naprej“ Tone Škrjanec. Blues zamaha: Ljubljana: KUD France Prešeren, 2008, 2. izdanje. 5-20.

Shaw, Lytle. Frank O'Hara: The Poetics of Côterie. Iowa City: University of Iowa Press, 2006.

Silverberg, Mark. The New York School Poets and the Neo-Avant-Garde Between Radical Art and Radical Chic. Farnham, Ashgate: 2010.

Swensen, Cole. „Introduction“, Cole Swensen, i David St. John (ur.), American Hybrid (A Norton Anthology of New Poetry). New York-London: Norton, 2009. xvii-xxvi.

Virk, Jani. „Predgovor“ Nenad Radlović i Jani Virk, J. (ur.), Strast in Mir: mlada slovenačka književnost. Beograd: Književna reč; Ljubljana: Literatura; Kikinda: Književna zadruga, 1990. 7-19.

Превео Иван Антић 
Alen Albin Širca

Genealogy of the Everyday: Slovene Poetry in Transition

Summary

The article attempts to detect and describe the change of the paradigm in the contemporary Slovene poetry. If most of the Slovene poetry after the Second World War, or to be more precise, from the late 1950s onwards, was written in the modernist key, with the "serious" existential themes and often dark and hermetic speech as prominent features, we may assume that in the 1980s this kind of poetry was slowly beginning to disintegrate. Although in this decade the so-called neo-avant-garde (or ultramodernist) poetry, which surfaced in the 1960s, became almost obsolete, the poetry of Tomaž Šalamun, the leading voice of the Slovene neo-avant-garde poetry, functioned as some sort of the major catalyst for the new poetry. If we may borrow the distinction between the "cooked" and "raw poetry", first used by Robert Lowell with regard to the new American poetry of the 1950s and 1960s, we can detect such new poetological tendencies which focus on the mundane themes of the everyday urban life, often written in a spontaneous and sometimes colloquial language, free of formal and metaphysical maneuvers of the so-called "academic", "cooked", or "moderate" modernism. To illuminate this poetological transition, the article focuses on the year 1991, which coincides with the disintegration of Yugoslavia and the formation of Slovenia as a new national state. In this year, many of the new young poets started their poetical careers. The brief analysis of the poetical debuts of the poets such as Brane Senegačnik, Vid Snoj, Miklavž Komelj, Jurij Hudolin, Peter Semolič, and Uroš Zupan attempts to demonstrate that most of the poets are still indebted to the modernist paradigm (with Dane Zajc and Niko Grafenauer as its main representatives), but nonetheless, in some cases, the traces of the new, "cooked" urban and narrative poetry can be observed on the margins of these debuts. These elements, however, are the most prominent in the book Sutre, written by Uroš Zupan, who also happens to be most influenced by the poetry of Tomaž Šlmun on the one hand and the American poetry of the beat generation and New York School on the other. These influences were of the utmost importance in the first stage of the new poetic paradigm that at the beginning of the 1990s strove to overcome the modernist literary tradition. The poetry of Uroš Zupan thus paved the way for the new mainstream of the contemporary Slovene poetry that appeared in the new millennium.

Keywords: Modernism, the everyday, "raw poetry", beat generation, Tomaž Šalamun, contemporary Slovene poetry, year 1991

Примљен: 1. јуна 2019

Прихваћен за објављивање: 15. фебруара 2020. 